\title{
Humanististen tieteiden fragmentit ja perustava rationaliteetti tietoon tai viestintään liittyvässä tutkimuksessa
}

\author{
Vesa Suominen \\ Oulun yliopisto \\ sohveli2012@gmail.com
}

Asiasanat: humanistiset tieteet; hermeneutiikka; positivismi; informaatiotutkimus; kirjastot - tutkimus

Kirjasto-, informaatio- ja dokumentaatiotutkimuksen (KID) teoreettismetodologisessa argumentaatiossa on 1900-luvun lopulta alkaen esiintynyt usein fragmentaariseksi jääviä, mutta toisinaan perustavanlaatuisiakin viittauksia esimerkiksi tyypillisesti humanististen tieteiden piiriin kuuluviin semiotiikkaan ja toisaalta hermeneutiikkaan (ks. esim. Capurro, 1992; Hansson, 2005; Mai, 2001; Suominen, 1997, 2016; Suorsa, 2017). Hermeneutiikan piirissä Hans-Georg Gadamer (1960/1992) kytkee humanististen tieteideen rationaliteetin varsin yksiselitteisesti tulkinnan kautta etenevään omaksumiseen (appropriaatioon) ja viime kädessä kulttuurillisen osallisuuden ylläpitoon ja edistämiseen ja sivistykseen (Bildung). Hän kritisoi esimerkiksi "historialliseksi objektivismiksi" (esim. op. cit., 266) kutsumaansa ajatustapaa. Tässä suhteessa saman suuntaisia ovat KID-tutkimuksessa olleet muun muassa konstruktionistiset pohdinnat esimerkiksi käsittein "objectified" ja "interpretative" (esim. Talja, Keso, \& Pietiläinen, 1999) tai "interpretationism" ja "positivism" (Spiranec, Banek Zorica, \& Kos, 2016) kuvatun jännitteen ympärillä.

Tässä on kuitenkin syytä tehdä seuraavanlainen kysymys. Missä määrin nuo viittaukset puhtaasti humanistisiin tieteisiin ja niiden käsitteistöön tai 


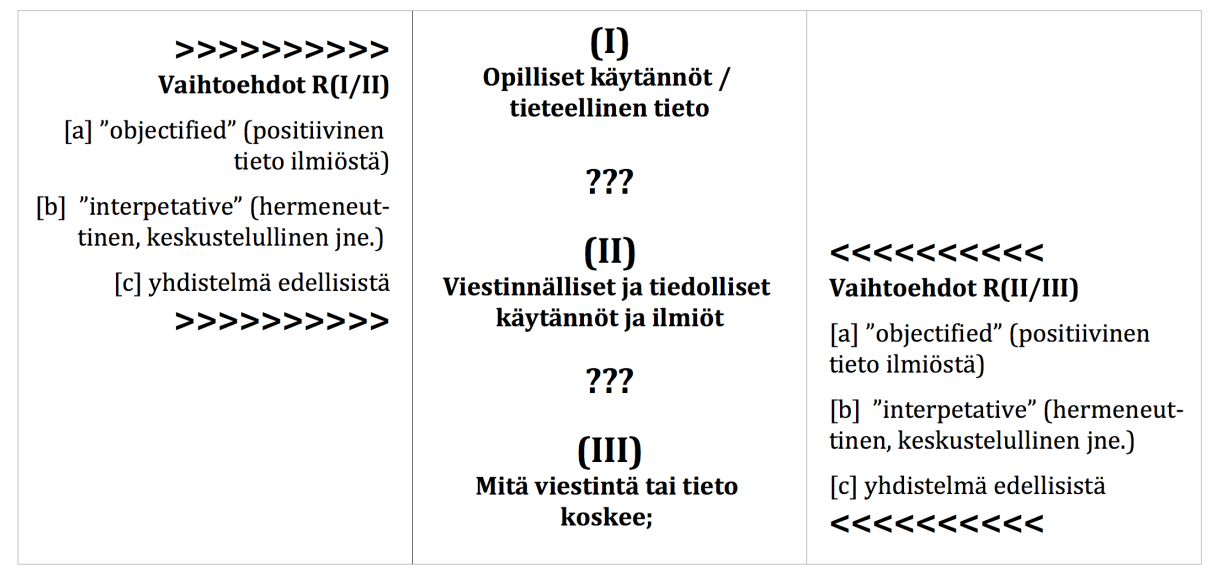

Kuva 1: Arkijärjen ontologian mukaiset tasot viestintään ja tietoon liittyvässä tutkimuksessa ja mahdollisuuksia niiden keskinäisten suhteiden käsittämiseksi (vrt. Suominen 2016, 272, Fig. 9. Relaatiot [a] ja [b], ks. Talja, Keso \& Pietiläinen, 1999; Spiranec, Zorica \& Kos 2016.)

samansuuntaiset positivismi-kriittiset pohdinnat voisivat olla johtamassa KID-tutkimukseen, joka todella voitaisiin käsittää osaksi humanistisia tieteitä?

Työkaluna sen ongelman analysoimiseksi erityisesti viestintään ja tietoon liittyvillä tutkimusaloilla - mukaan lukien KID-tutkimus - voimme käyttää skeemaa (Kuva 1), jota olen hieman modifioinut aikaisemmin esittämästäni (Suominen, 2016, s. 272). Viestintään ja tietoon liittyen sekä itse tutkimus että myös tutkittava ilmiö tai käytäntö voidaan ymmärtää viestinnällisinä ja/tai tiedollisina tapahtumina, jolloin kysymykset esimerkiksi objektivismista tai tulkinnallisuudesta asettuvat ikään kuin kahdella tasolla. Tutkimuksen ja oppineisuuden rationaliteettien kompleksisuudesta johtuen on tarpeen vielä askelluksen (stepping order) käsitteeni (op.cit, 257-). Jo Kuvan 1 tasojen järjestys voi kuvata tätä askellusta ja samalla tutkimuksen preusrationaliteettia ja pyrkimystä, jonka osoittaa tasojen (I) ja (II) suhde R(I/II). Käsittein hallitseva ja alisteinen avulla voimme kuvata vielä vaihtoehdon $[\mathrm{c}]$ tarkempaa rakentumista ja sitä kautta tutkimuksen perusrationaliteettia silloinkin, kun tasojen järjestys sinänsä ei riitä.

Joacim Hanssonin esittää erittäin oivaltavan ja sattuvan hermeneutiikan asemaa KID-tutkimuksessa (tai "kirjastotieteessä ja informatiikassa", "LIS”) koskevan kysymyksen:

There seems to be confusion over the very object of hermeneutics. Although a general understanding of the concept implies interpre- 
tation as a way of scientific discovery and analysis, the majority of LIS scholars speak of the very practice we study as hermeneutics. Librarianship is hermeneutic, information (or, rather, document) retrieval is hermeneutic, information management is hermeneutic, but the study of these practices-that what righteously should be called LIS-is what? (Hansson, 2005, s. 108. Kursivointi VS)

Hanssonin tyypilliseksi alalla kuvaamaa pyrkimystä voimme luonnehtia sofistikoiduksi positivismiksi. Kuvan 1 mukaisesti sofistikoitua positivismia voisi kuvata seuraavasti:

- $\mathrm{R}(\mathrm{I} / \mathrm{II})=[\mathrm{a}]$ (mikä määrittää perusrationaliteetin positivistiseksi)

- $\mathrm{R}(\mathrm{II} / \mathrm{III})=[\mathrm{b}]$ tai $[\mathrm{c}]$ (mikä määrittää positivismin sofistikoiduksi)

Perusasetelmaa ei muuta - vaikka sofistikaatiotasoa voi nostaa - esimerkisi $\mathrm{R}(\mathrm{I} / \mathrm{II})$ suhteessa alisteisena oleva tulkinnallisuus vaikkapa empiirisen aineiston hankinnassa ja käsittelyssä.

Esityksessä havainnollistan tässä esitettämääni analyysitapaa esimerkein, jotka edustavat yhtäältä (i) sofistikoitua positivismia ja toisaalta kombinaatiota, jota voimme luonnehtia (ii) aidosti hermeneuttiseksi. Lisäksi tarkastelen sitä, mitä erilaiset tutkimusta määrittävät (iii) kriittisen pyrkimykset voivat edellyttää.

Kuvaamani kaltaisen analyysin avulla on mahdollista avartaa näkemystämme mahdollisista ja mielekkäistä tieteellisistä ja opillisista rationaliteeteista KIDtutkimuksen piirissä. Tällä olisi merkitystä ehkä erityisesimmin kirjastotutkimuksen ja kirja- tai dokumentaatiohistoriallisen bibliografian kannalta.

\section{Lähteet}

Capurro, R. (1992). What is information science for? A philosophical reflection. Teoksessa P. Vakkari \& B. Cronin (toim.), Conceptions of Library and Information Science: Historical, Empirical, and Theoretical Perspectives (ss. 82-86). London, UK, UK: Taylor Graham Publishing.

Hansson, J. (2005). Hermeneutics as a bridge between the modern and the postmodern in library and information science. Journal of Documentation, 61(1), 102-113. https://doi.org/10.1108/00220410510578032

Mai, J. (2001). Semiotics and indexing: an analysis of the subject indexing process. Journal of Documentation, 57(5), 591-622. https://doi.org/10.1108/ EUM0000000007095 
Spiranec, S., Banek Zorica, M., \& Kos, D. (2016). Information Literacy in participatory environments: The turn towards a critical literacy perspective. Journal of Documentation, 72(2), 247-264. https://doi.org/10.1108/JD-062015-0072

Suominen, V. (1997). Filling empty space : a treatise on semiotic structures in information retrieval, in documentation, and in related research. Oulu: University of Oulu.

Suominen, V. (2016). About and on behalf of scriptum est : the literary, bibliographic, and educational rationality sui generis of the library and librarianship on the top of what literature has produced. Oulu: University of Oulu. http://urn.fi/urn:isbn:9789526212302

Suorsa, A. (2017). Interaction for knowledge creation : a phenomenological study in knowledge management (Vsk. 149). Oulu: University of Oulu. http:// urn.fi/urn:isbn:9789526215228

Talja, S., Keso, H., \& Pietiläinen, T. (1999). The production of "context" in information seeking research: a metatheoretical view. Information Processing \& Management, 35(6), 751-763. https://doi.org/10.1016/S0306-4573(99)00024- 